\title{
Identification of residues in the putative TolA box which are essential for the toxicity of the endonuclease toxin colicin E9
}

\author{
Carole Garinot-Schneider, ${ }^{1}$ Christopher N. Penfold, ${ }^{1}$ Geoffrey R. Moore, ${ }^{2}$ \\ Colin Kleanthous' and Richard James ${ }^{1}$
}

School of Biological Sciences ${ }^{1}$ and School of Chemical Sciences ${ }^{2}$ University of East Anglia, Norwich NR4 7TJ, UK
Author for correspondence: Richard James. Tel: +44 1603 592197. Fax: +441603592250. e-mail: r.james@uea.ac.uk

\begin{abstract}
E colicins are plasmid-coded, protein antibiotics which bind to the BtuB outer membrane receptor of Escherichia coli cells and are then translocated either to the outer surface of the cytoplasmic membrane in the case of the pore-forming colicin E1, or to the cytoplasm in the case of the enzymic colicins E2-E9. Translocation has been proposed to be dependent on a putative TolA box; a pentapeptide (DGSGW) located in the $\mathbf{N}$-terminal 39 residues of several Toldependent colicins. In this study, site-directed mutagenesis was used to change each of the residues of the putative TolA box of colicin E9 to alanines. In the case of the two glycine residues, the resulting mutant proteins were indistinguishable from the native colicin E9 protein in a biological assay; whereas the other three residues when mutated to alanines resulted in a complete loss of biological activity. Mutagenesis of two serine residues flanking the putative TolA box, Ser34 and Ser40, to alanines did not abolish the biological activity of the mutant colicin E9, although the zones of growth inhibition were hazy and slow to form. The size of the zone of inhibition was significantly smaller than the control in the case of the Ser40Ala mutant. The ColE9/Im9 complex was isolated from the three biologically inactive TolA box alanine mutants. In competition assays all three mutant protein complexes were capable of protecting sensitive $E$. coli cells against killing by the native ColE9/Im9 complex. On removal of the $I \mathrm{~m} 9$ protein from the three mutant ColE9/Im9 complexes, all three mutant colicins exhibited DNase activity. These results confirm the importance of the putative TolA box in the biological activity of colicin E9, and suggest that the TolA box has a role in the translocation of colicin E9.
\end{abstract}

Keywords: E colicins, translocation, protein-protein interaction, TolA protein, BtuB receptor

\section{INTRODUCTION}

Colicins are plasmid-encoded antibacterial proteins that are classified into groups on the basis of the cell surface receptor to which they bind. The E colicins, for example, all bind to the product of the chromosomal $b t u B$ gene, which is an essential component of the high-affinity transport system for vitamin $\mathrm{B}_{12}$ in Escherichia coli (Di Masi et al., 1973). Each E colicin plasmid codes for the production of a specific immunity protein which protects the producing cell against the cytotoxic activity of its colicin, located at the C-terminus of the protein, by binding to this domain (Jakes et al., 1974; Sidikaro \&
Nomura, 1974; Wallis et al., 1992a, b). Based on immunity tests (Watson et al., 1981; Cooper \& James, 1984) the E group colicins have been subdivided into nine types (ColE1-ColE9), and these fall into one of three cytotoxic classes: membrane-depolarizing (or pore-forming) agents such as ColE1 (Cramer et al., 1990), DNases such as colicins E2, E7, E8 and E9 (Lau et al., 1992) and RNases such as colicins E3, E4, E5 and E6 (Masaki et al., 1992). The DNase- and RNase-type E colicins constitute a group called the enzymic E colicins (James et al., 1996).

After binding to specific receptors in the outer mem- 
brane, colicins are translocated across the outer membrane in a process which is mediated by the Ton (Braun, 1995) or the Tol system (Lazdunski, 1995). The TonBExbB-ExbD complex facilitates the flow of energy from the cytoplasm to the outer membrane for the energydependent transport of ferric siderophore complexes, vitamin $B_{12}$ and group B colicins (Braun, 1995). It has been proposed that an energized conformation of the TonB protein opens channels in the outer membrane, formed by receptor proteins like FepA, which acts as a receptor for colicins $B$ and $D$ and for ferric siderophores, or $\mathrm{BtuB}$, which is a receptor for vitamin $\mathrm{B}_{12}$.

The Tol-dependent translocation pathway is used both for the uptake of group A colicins (colicins A, E1 to E9, $\mathrm{K}, \mathrm{L}, \mathrm{N}$ and S4) and for the DNA of filamentous phages (Lazdunski, 1995). Four gene products are involved, tolQ, tolR, tolA and tolB, which are clustered at $17 \mathrm{~min}$ on the E. coli chromosomal map (Webster, 1991). The TolA, TolB, TolQ and TolR proteins are required to translocate colicins A, E2-E9, K and N; whilst only the TolC, TolA and TolQ proteins are required to translocate colicin E1. The nucleotide sequence of the $t o l$ genes has been determined and the Tol proteins have been localized in the $E$. coli cell envelope. The TolQ, TolR and TolA proteins are associated with the cytoplasmic membrane. TolQ contains three membranespanning segments (Kampfenkel \& Braun, 1993). TolA and TolR are anchored to the cytoplasmic membrane by their N-terminal domains, whilst TolB is principally located in the periplasm, but is associated with the outer membrane (Isnard et al., 1994), through an interaction with the peptidoglycan-associated protein (Pal) (Bouveret et al., 1995). TolC is an outer-membrane protein which is able to form pores in vitro (Benz et al., 1993) and is also involved in the secretion of $\alpha$ haemolysin (Wandersman \& Delepelaire, 1990) and colicin V (Gilson et al., 1990).

The TolA protein is believed to perform a central role in the Tol-dependent translocation pathway (Levengood et al., 1991). It is composed of three domains: the Nterminal domain of some 40 amino acids which anchors the protein in the cytoplasmic membrane, a central domain of some 260 amino acids which spans the periplasmic space, and a C-terminal domain of some 120 amino acids. Interactions between the $\mathrm{N}$-terminal domain of both colicin A and E1 with the C-terminal domain of TolA have been demonstrated in vitro by Western blotting of total cell proteins of $E$. coli cultures that overproduce the TolA protein (Bénédetti et al., 1991). After renaturation of the proteins on the filter and incubation with colicins, binding to the TolA protein was detected by using specific antibodies. The results showed that the Tol-dependent colicins $A$ and E1 were able to interact with TolA, whilst the TonB-dependent colicin B was not. The $\mathrm{C}$-terminal region of TolA was required for the colicin binding to occur, although the isolated $\mathrm{N}$-terminal domain of colicin $\mathrm{A}$, corresponding to the translocation domain, was sufficient for binding. It is tempting to speculate that the in vitro interaction between TolA and colicins A and E1 may be of importance in the translocation process in vivo.

The N-terminal translocation domains of group B colicins contain a pentapeptide motif, called the 'TonB box', which is also found in the FepA and BtuB receptor proteins (Schramm et al., 1987). Mutations in the TonB box of group B colicins (or in their receptors) reduce colicin uptake (Mende \& Braun, 1990), and can be suppressed by mutations in TonB (Braun, 1995). Such allele-specific extragenic suppression indicates physical and functional interaction between group B colicins, their receptors and TonB. In contrast to the situation with group B colicins, very little is known about the role of specific residues of the translocation domain itself in the uptake of group A colicins. A number of hybrid colicins have been constructed by recombining colicin domains of Tol- and Ton-dependent colicins. The properties of these hybrid colicins clearly demonstrate that the translocation pathway is defined by the $\mathrm{N}$ terminal domains (Bénédetti et al., 1992). N-terminal fragment swaps between colicin E1 and colicin 10, poreforming colicins which use the Tol and the Ton uptake systems respectively, confirmed that the Tol dependence of colicin E1 uptake was located in residues 1-34 (Pilsl \& Braun, 1995a). Comparison of the Tol-dependent colicins E1, E2 and E3 revealed a consensus pentapeptide sequence $D G(T / S) G(S / W)$, located in the various colicins between residues 30 and 39 , at a similar position to the TonB box of Col10. This pentapeptide has been referred to as the 'TolA box' (Pilsl \& Braun, 1995a), although there is no direct experimental evidence that these specific amino acids are essential in the translocation process. One intriguing question is the difference between the translocation of pore-forming colicins and the enzymic E colicins (James et al., 1996); the former are translocated to the outer surface of the cytoplasmic membrane, whilst the latter have to be present in the cytoplasm to exhibit their cytotoxic activity. In this work we have investigated the involvement of a number of amino acids, including the putative TolA box residues, in the biological activity of the enzymic colicin E9.

\section{METHODS}

Plasmids, bacterial strains and media. E. coli JM83 was used as the host strain for cloning and mutagenesis. E. coli BL21(DE3) was used as the host strain for the expression vector pET21a (Novagen), which has a strong, IPTG-inducible $\mathrm{T} 7$ polymerase promoter and a polyhistidine tag (His $\cdot$ tag) to facilitate the purification of overexpressed proteins. All cultures were routinely grown in Luria-Bertani (LB) broth, or on plates of LB agar, supplemented where required with ampicillin $\left(100 \mu \mathrm{g} \mathrm{ml}^{-1}\right)$. Plasmid pR J358, which encodes the colicin E9 structural gene (ceal) and the Im9 immunity gene (ceil), has previously been described (Garinot-Schneider $e t$ al., 1996).

DNA manipulation. Restriction enzymes and T4 DNA ligase were purchased from Boehringer Mannheim or New England Biolabs. Digestion of DNA with restriction endonucleases, electrophoresis of restriction fragments, ligation of DNA 
fragments and transformation into $E$. coli were carried out as described by Sambrook et al. (1989).

PCR. PCR reactions were carried out in $50 \mu$ volumes using 1 unit of Taq polymerase with 30 cycles of $94^{\circ} \mathrm{C}$ for $1 \mathrm{~min}$, $55^{\circ} \mathrm{C}$ for $1 \mathrm{~min}$ and $72{ }^{\circ} \mathrm{C}$ for $1 \mathrm{~min}$, using an Amplitron II thermal cycler.

Colicin production tests. Test cultures were stabbed into plates of LB agar containing ampicillin and were incubated overnight at $37^{\circ} \mathrm{C}$ before exposure of the plates to chloroform vapour for $15 \mathrm{~min}$. After allowing residual chloroform to evaporate for $1 \mathrm{~h}$, the plates were overlaid with $4 \mathrm{ml}$ molten $0.7 \%(\mathrm{w} / \mathrm{v})$ non-nutrient agar containing $50 \mu \mathrm{l}$ of a standing overnight culture of the colicin-sensitive indicator strain $E$. coli JM83(pUC18). After incubation of the plates at $37^{\circ} \mathrm{C}$ for at least $6 \mathrm{~h}$ the plates were inspected for a clear zone of growth inhibition around the test culture. Each culture was tested independently at least three times.

Total cell protein extracts of colicin-producing cultures. Standing overnight cultures were diluted 100 -fold in $5 \mathrm{ml} \mathrm{LB}$ broth containing ampicillin and shaken at $37^{\circ} \mathrm{C}$ for $2 \mathrm{~h}$ $\left(\mathrm{OD}_{600} \sim 0.2-0.4\right)$. At this point $2.5 \mathrm{ml}$ of culture was transferred to a second flask containing mitomycin $\mathrm{C}$ $\left(0.5 \mu \mathrm{g} \mathrm{ml}^{-1}\right)$. About $2 \mathrm{~h}$ after induction with mitomycin $\mathrm{C}$, when the $\mathrm{OD}_{600}$ was more than $1 \cdot 0,2 \mathrm{ml}$ of the culture from each flask was centrifuged at $13000 \mathrm{~g}$ for $30 \mathrm{~s}$. The cell pellets were then resuspended in $100 \mu \mathrm{l} 1 \times$ SDS-loading buffer [25 mM Tris/HCl pH 6.8, $1 \%$ (w/v) SDS, $5 \%$ (w/v) glycerol, $0.1 \%$ bromophenol blue], boiled for $5 \mathrm{~min}$ and re-centrifuged. The supernatants (total cell proteins) were stored at $-20^{\circ} \mathrm{C}$ until required.

SDSPAGE. SDS-PAGE gels $(10 \%$ or $15 \%, \mathrm{w} / \mathrm{v}$, acrylamide) were prepared and loaded with samples of total cell proteins, or of purified proteins, using the mini-Atto gel system following the protocol recommended by the manufacturer. The SDS-PAGE gels were stained for proteins with Coomassie blue for $1 \mathrm{~h}$ and then de-stained.

PCR site-directed mutagenesis. A mutagenic primer was used in a PCR reaction together with forward PCR primer S30, which is complementary to a $20 \mathrm{bp}$ sequence located $105 \mathrm{bp}$ upstream of the start codon of the ceal gene in the template plasmid pNP11. After isolation of the first PCR product with a Qiaex II kit (Qiagen), a second PCR reaction was performed using the first PCR product as a 'megaprimer' together with the reverse PCR primer S19, which is complementary to a sequence at 612 bp of the ceal gene in pNP11. The second PCR product containing the desired mutation was then purified, restricted with NdeI and EcoRV, and cloned in pNP11 restricted with the same enzymes. The nucleotide sequence of the complete NdeI-EcoRV restriction fragment was determined, using a Pharmacia ALF automated DNA sequencer, to confirm that the expected mutation had been made.

Protein purification and protein determinations. The protocol for His.tag protein purification of the ColE9/Im9His - tag complexes was adapted from that provided in the manufacturer's (Novagen) user manual. Fifty millilitres of LB broth (containing $50 \mu \mathrm{g}$ ampicillin $\mathrm{ml}^{-1}$ ) was inoculated with $0.5 \mathrm{ml}$ of an overnight culture of $E$. coli BL21(DE3) containing the mutant plasmid and incubated at $37^{\circ} \mathrm{C}$ with shaking. At an $\mathrm{OD}_{600}$ of 0.6 overexpression was induced by adding IPTG to a final concentration of $1 \mathrm{mM}$. Growth was continued for a further $2-3 \mathrm{~h}$. The cultures were centrifuged for $15 \mathrm{~min}$ at 10000 r.p.m. The cells were washed in $15 \mathrm{ml}$ ice-cold binding buffer $(5 \mathrm{mM}$ imidazole, $500 \mathrm{mM} \mathrm{NaCl}, 20 \mathrm{mM}$ Tris/ $\mathrm{HCl}$, $\mathrm{pH} 7 \cdot 5$ ), and the cell pellet was stored at $-80^{\circ} \mathrm{C}$ for $24 \mathrm{~h}$. The cell pellet was resuspended in $4 \mathrm{ml}$ ice-cold binding buffer, treated with $200 \mu \mathrm{l}$ lysozyme $\left(20 \mathrm{mg} \mathrm{ml}^{-1}\right)$ for $30 \mathrm{~min}$ at $37^{\circ} \mathrm{C}$, and then subjected to freezing and thawing (three times) to break the cell walls. Nucleic acids were degraded with DNase I and RNase A, and the bacterial suspension was centrifuged at 14300 r.p.m. for $20 \mathrm{~min}$. The post-centrifugation supernatant was filtered through a $0.45 \mu \mathrm{m}$ membrane. A $1.0 \mathrm{ml}$ $\mathrm{Ni}^{2+}$ column was charged with $5 \mathrm{ml}$ charge buffer $(50 \mathrm{mM}$ $\mathrm{NiSO}_{4}$ ), and then equilibrated with $3 \mathrm{ml}$ binding buffer. The prepared cell extract was then loaded on to the column. The column was washed with $8 \mathrm{ml}$ binding buffer, $4 \mathrm{ml}$ wash buffer $(60 \mathrm{mM}$ imidazole, $500 \mathrm{mM} \mathrm{NaCl}, 20 \mathrm{mM}$ Tris/ $\mathrm{HCl}$, $\mathrm{pH} 7.5)$ and the colicinE9/Im9 complex was eluted with elution buffer ( $1 \mathrm{M}$ imidazole, $500 \mathrm{mM} \mathrm{NaCl}, 20 \mathrm{mM}$ Tris/ $\mathrm{HCl}, \mathrm{pH} 7 \cdot 5)$. The elution was monitored by Bradford assay of aliquots at $595 \mathrm{~nm}$ and by running samples on SDS-PAGE. Although considerable amounts of the ColE9/Im9 complex were eluted with the wash buffer, the purity of the ColE9/Im9 complex recovered in the elution buffer was found to be significantly higher (see Fig. 3). Protein-containing fractions were dialysed exhaustively against water and the protein lyophilized prior to storage at $-20^{\circ} \mathrm{C}$. The yield of protein from a typical purification was $20-30 \mathrm{mg}$ (1 bacterial culture) $)^{-1}$.

Preparation of free colicin. Colicin E9 was purified in the absence of Im9-His - tag, by eluting from the $\mathrm{Ni}^{2+}$ column under denaturing conditions, with binding buffer containing $6 \mathrm{M}$ guanidine hydrochloride. Guanidine hydrochloride denatures the ColE9/Im9-His-tag complex, thus removing the colicin whilst leaving Im9-His - tag bound to the column. Colicin E9 was then renatured by dialysis against water. Previous studies have shown that guadinine-hydrochloridedenatured colicin E9 can be refolded by dialysis and that full biological activity is restored to the colicin (Wallis et al., 1992a). The presence of Im9-His-tag-free colicin E9 was determined by SDS-PAGE. Purified Im9 was a gift from C. Giffard, University of East Anglia.

Receptor binding assay of ColE9/Im9complexes. An overnight culture of sensitive E. coli JM83(pUC18) cells was diluted 100fold into $100 \mathrm{ml} \mathrm{LB}$ broth containing ampicillin, and grown at $37^{\circ} \mathrm{C}$ to an $\mathrm{OD}_{600}$ of $0 \cdot 1$. Aliquots $(10 \mathrm{ml})$ were then transferred to clean, sterile flasks and the cells were incubated with $1.2 \mu \mathrm{g}$ ColE9/Im9-His $\cdot$ tag and either $1 \cdot 2,12$, or $120 \mu \mathrm{g}$ mutant ColE9/Im9-His - tag at $37^{\circ} \mathrm{C}$ for at least $5 \mathrm{~h}$. The concentration of ColE9/Im9-His-tag used was the lowest concentration which significantly affected the growth of $E$. coli JM83(pUC18), as judged by measuring the increase in $\mathrm{OD}_{600}$. Cells containing $1.2 \mu \mathrm{g}$ native or mutant colicin only, or no colicin at all, were included as controls. The $\mathrm{OD}_{600}$ of each sample treatment was taken at $30 \mathrm{~min}$ intervals to monitor cell viability. Each competition assay was performed at least twice with each mutant ColE9/Im9-His•tag complex being tested.

DNase activity assay. DNase activity assays were done as previously described (Wallis et al., 1992a). Each digest contained $200 \mathrm{ng}$ pUC18 DNA and colicin E9 (610 ng; $10 \mathrm{pmol})$, in the presence and absence of $\operatorname{Im} 9(98 \mathrm{ng} ; 10 \mathrm{pmol})$, and was repeated at least twice.

\section{RESULTS}

\section{Alignment of the $\mathrm{N}$-terminal domains of Tol-dependent colicins}

Comparison of the Tol-dependent colicins E1, E2 and E3 revealed a consensus pentapeptide sequence $\mathrm{DG}(\mathrm{T} / \mathrm{S}) \mathrm{G}(\mathrm{S} / \mathrm{W})$, located in the various colicins be- 
MPGFNYGGKG

METAVAYYKD GVPYDDKGQV IITLLNGTP

10

20

30

MSGGDGRGHN TGAHSTSGNI NGGPTGLGVG

MSGGDGRGHN TGAHSTSGNI NGGPTGIGVS

MSGGDGRGHN SGAHNTGGNI NGGPTGLGGN GGASDGSGWS S

MSGGDGRGHN TGAHSTSGNI NGGPTGLGVG GGASDGSGWS S

MSGGDGRGHN TGAHSTSGNI NGGPTGLGVG GGASDGSGWS SEN
DGTGWS SERGSGPEPG GGSHGNSGGH DRGD A

DGSGSG GGGGKGGSKS ESSAAIHATA KWST E1

40

50

60

\section{MAKELSGYGP TAGESM}

MGSNGADNAH NNAFGGGKNP GIGNT

\author{
GGTGAN LNQQGGNNNS NSGVHWGGGS GHGN K \\ SGAGSN GSASSNRGNS NGWSWSNKPH KNDG N
}

Fig. 1. An alignment of the $\mathrm{N}$-terminal amino-acids of Tol-dependent colicins. The $\mathrm{N}$-terminal amino-acid sequences of two pore-forming colicins, E1 and A, which are translocated by the Tol-dependent translocation system are aligned with colicin E3, an enzymic colicin. This alignment suggested the TolA box sequence in all three colicins (Pilsl \& Braun, 1995a), which is shown in bold type. Including the $\mathrm{N}$-terminal amino acids from four other enzymic $\mathrm{E}$ colicins supports this alignment but also suggests another possible Tol box sequence from residues 5 to 9 , which is underlined. The putative TolA box sequence of colicin K (Pilsl \& Braun, 1995b) and the only similar sequence in colicin N are aligned with the TolA box. Padding characters have been added to the colicin $A, E 1, K$ and $N$ sequences to optimize the alignment.

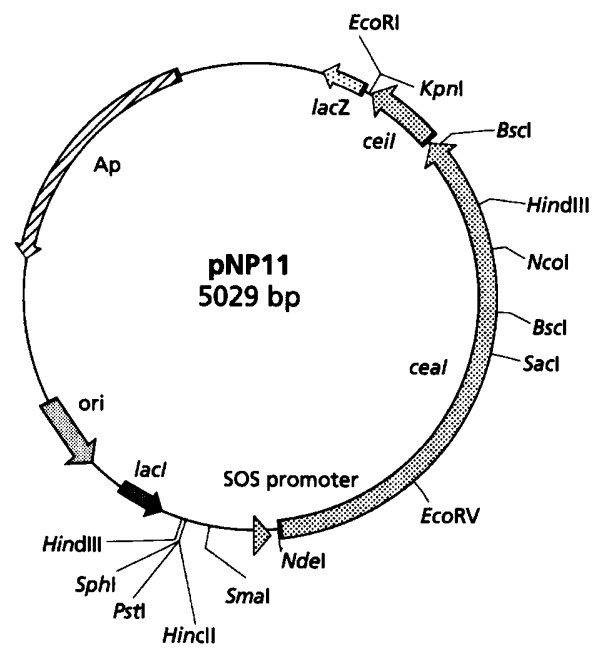

Fig. 2. Restriction map of pNP11. The relative positions and the orientation of the ceal and the ceil genes are shown by arrows. The Ndel and EcoRV sites were used to facilitate site-directed mutagenesis of the putative TolA box residues, whilst the Ndel and Ncol sites were used to facilitate purification of mutant ColE9/Im9 His - tag complexes.

tween residues 30 and 39 , at a similar position to the TonB box of Col10. This pentapeptide was thus referred to as the 'TolA box' (Pilsl \& Braun, 1995a). The putative TolA box is also present, at residues $35-39$, in all the other enzymic $\mathrm{E}$ colicins whose sequence has been determined (Fig. 1). Mutation of Ser37 to Phe had previously been shown to abolish the biological activity of colicin E3 (Escuyer \& Mock, 1987). It is of interest, however, that the suggested TolA box of the pore- forming colicin K (GGTGA) (Pilsl \& Braun, 1995b) shows much less sequence homology to the putative TolA box of the enzymic E colicins. The only similar pentapeptide sequence in the $\mathrm{N}$-terminal fragment of the pore-forming colicin $\mathrm{N}$, another member of the Toldependent group A colicins, appears to be SGAGS. We therefore decided to determine the significance of the five residues of the putative TolA box in the biological activity of colicin E9.

\section{Construction of plasmid pNP11}

To facilitate the isolation and characterization of sitedirected mutants of the putative TolA box of colicin E9, we constructed plasmid pRJ364, which is derived from pRJ358 (Garinot-Schneider et al., 1996) by the introduction of an EcoRV site at $490 \mathrm{bp}$ of the ceal gene, using PCR site-directed mutagenesis. An NdeI site was also introduced at the initiation codon of the ceal gene, together with a SacI site at $993 \mathrm{bp}$. The resulting plasmid pNP11 (Fig. 2) was then used as the template for mutagenesis of the putative TolA box residues, and for the biological characterization of the resulting mutants.

\section{Mutagenesis of residues in the translocation domain of colicin E9}

We have recently shown the value of alanine scanning mutagenesis of mutations localized in the DNase domain of colicin E9 which abolish the biological activity of colicin E9. Two out of six random mutations which abolished the biological activity of colicin E9 gave fully active colicins when the corresponding residues were mutated to alanine (Garinot-Schneider et al., 1996), possibly because the original mutations in these two 


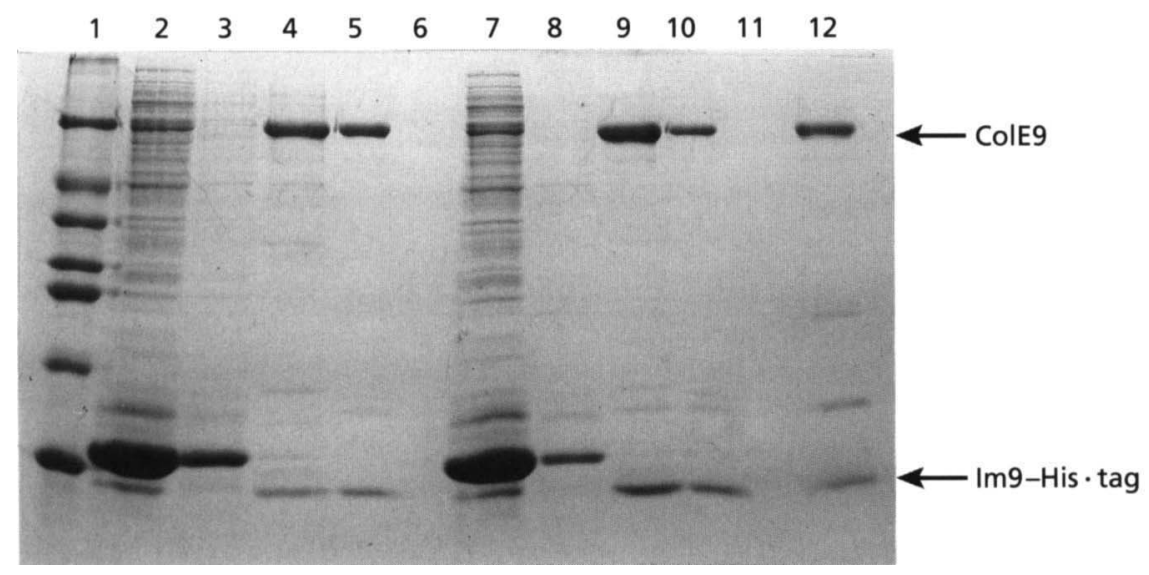

Fig. 3. His.tag purification of two of the
mutant ColE9/lm9-His.tag complexes. The
purification of the $61555 \mathrm{Da}$ colicin E9 and
the $10649 \mathrm{Da}$ Im9-His.tag proteins as a
complex was confirmed by SDS-PAGE on a
$15 \%$ gel. Lane 1, marker proteins $(66 \cdot 0,45 \cdot 0$,
$36 \cdot 0,29 \cdot 0,24 \cdot 0,20 \cdot 1,14 \cdot 2 \mathrm{kDa}) ;$ lanes 2 and
7, total cell proteins from a culture
producing the Asp35Ala and the Trp39Ala
mutant colicin respectively; lanes 3 and 8 ,
eluate from the binding buffer step; lanes 4
and 9 , eluate from the wash buffer step;
lanes 5 and 10, eluate from the elution
buffer step; lane 12 , sample of the native
ColE9//m9-His.tag complex. The relative
mobilities of the colicin E9 and Im9-His.tag
proteins are identified on the right.

Table 1. Colicin phenotype of alanine mutants of colicin E9

The residue shown in colicin E9 was mutated to alanine, using site-directed mutagenesis. The colicin phenotype of the resulting colicin was determined in a stab test. The size of the zone of inhibition encoded by the mutant plasmids is quantified with respect to that encoded by plasmid pNP11 (* indicates that although the zone of inhibition was similar in size to that of the control, it was hazy and slow to form; - , no zone of inhibition).

\begin{tabular}{|lc|}
\hline Residue & Phenotype \\
\hline None & +++++ \\
Ser34 & $+++++^{*}$ \\
Asp35 & - \\
Gly36 & ++++ \\
Ser37 & - \\
Gly38 & +++++ \\
Trp39 & - \\
Ser40 & $+++^{*}$ \\
Ser52 & +++++ \\
Trp56 & +++++ \\
\hline
\end{tabular}

mutants disrupted the structure of the protein. Since the Ser37Phe mutation which abolished the biological activity of colicin E3 (Escuyer \& Mock, 1987) might have a significant effect on protein structure, we made a Ser37Ala mutant of colicin E9 in pNP11, using PCR mutagenesis. The $\mathrm{Col}^{-}$phenotype of the Ser37Ala mutant colicin confirmed the importance of this residue to the biological activity of colicin E9. SDS-PAGE of total cell proteins from a mitomycin-C-induced culture confirmed that the Ser37Ala mutant colicin is induced at similar levels to the native colicin E9 by mitomycin C, and is not inherently unstable (data not shown).

Mutagenesis of the other four residues of the putative TolA box revealed that converting either of the two Gly residues (Gly36 and Gly38) to Ala had no effect upon the biological activity of the mutant colicin E9, whilst mutation of Asp35 or Trp39 to Ala completely abolished the biological activity of the mutant colicin E9 (Table 1).
The loss of biological activity of the Asp35Ala and the Trp39Ala mutant colicins was not due to differences in induction or stability (Fig. 3). To confirm the importance of the putative TolA box residues, we also mutated the flanking residues Ser34 and Ser40 to alanine residues. Neither of these mutations abolished the biological activity of colicin E9 (Table 1), but there was a noticeable difference, compared with the native colicin/ Im9 complex, in that the zones of inhibition formed in the stab test were hazy and slow to appear. In the case of the Ser40Ala mutant, the zone of inhibition was significantly smaller than that of the control. An alternative pentapeptide sequence, DGRGH, located at residues 5-9, which showed some homology to the putative TolA box was found, but mutagenesis showed that residues 5-9 have no special role in the translocation process of colicin E9. The Arg7Ala mutation had a slight effect on the colicin phenotype, resulting in a slightly smaller zone of inhibition in the stab test. The only other significant homology in Fig. 1 was between residues 52 and 64 (SG(V/I)HWGGGSGHGN) in the enzymic E colicins with residues 34-46 of colicin K (SGVHWGGGSGHGN), which has been previously reported (Pilsl \& Braun, $1995 \mathrm{~b})$. We therefore decided to mutate Ser 52 and Trp56 of colicin E9 to Ala residues. The resulting mutant colicins were as active as the control colicin E9 in stab tests (Table 1).

\section{Purification of the mutant ColEg/Im9 complexes}

We have shown previously that a polyhistidine tail on Im9 facilitates the purification of the $15 \mathrm{kDa}$ DNase domain of colicin E9, when both proteins are coexpressed in T7 expression vectors (Wallis et al., 1994; Garinot-Schneider et al., 1996). To facilitate the purification of the ColE9/Im9 complex, we therefore introduced an XhoI site in place of the stop codon of the ceil gene of plasmid pNP11 during a PCR reaction. The 2012 bp NdeI-XboI PCR fragment, containing the ceal and ceil genes, was then cloned into plasmid pET21a restricted with the same enzymes. The resulting plasmid, pCS4, was then transformed into E. coli BL21(DE3). IPTG-induced cultures of $E$. coli BL21(DE3) containing pCS4 were shown to overexpress the $61555 \mathrm{Da}$ colicin 

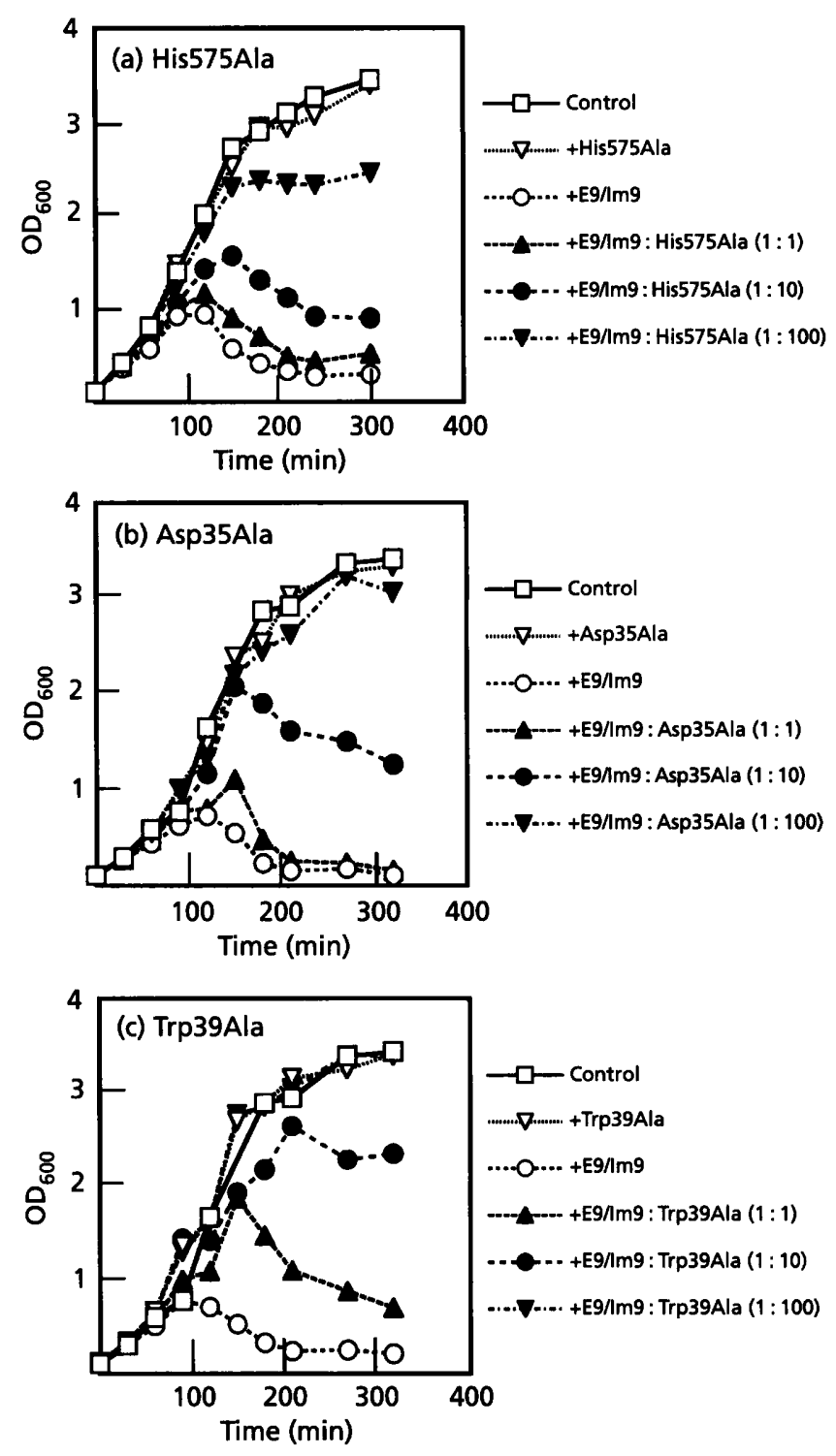

Fig. 4. Competition assay of the three mutant ColE9/Im9-His.tag complexes. Results of the competition assay are shown for two of the TolA box mutants, Asp35Ala (b) and Trp39Ala (c), and are compared with that of the His575Ala mutant (a) of colicin E9, which is biologically inactive due to a mutation in the DNase domain (Garinot-Schneider et al., 1996). The results with the Ser37Ala mutant have previously been shown (Garinot-Schneider, 1996), and are very similar to the other two TolA box mutants.

E9 protein, together with a $10649 \mathrm{Da} \operatorname{Im} 9$ protein which contained two extra residues and a polyhistidine tail at the C-terminus. Soluble protein extracts from these cultures were used to purify the ColE9/Im9-His-tag complex. The 1345 bp NdeI-NcoI fragment of each of the three alanine mutants of the putative TolA box which abolish the biological activity of colicin E9 was sub-cloned into pCS4 restricted with NdeI and Ncol. E. coli BL21(DE3) cultures containing the resulting plasmids were then induced with IPTG and the mutant ColE9/Im9-His·tag complexes were purified (Fig. 3).
The mutant ColE9/Im9-His-tag complexes as eluted from the nickel affinity column were judged to be $>90 \%$ pure from the Coomassie-stained gels, thus showing the value of this rapid purification strategy.

\section{Characterization of the mutant ColE9/Im9 complexes}

Since the three alanine mutants we had constructed had mutations in the putative TolA box sequence, we would ideally wish to test the three mutant ColE9/Im9 complexes in an in vivo, or in vitro assay of translocation. Unfortunately, the only assay of this type is the in vitro demonstration of an interaction between the $\mathrm{N}$ terminal domain of either colicin A or E1 with the Cterminal domain of TolA (Bénédetti et al., 1991). Under the same experimental conditions there is no interaction between the $\mathrm{N}$-terminal domain of the enzymic colicin E3 with TolA ( $\mathrm{H}$. Bénédetti, personal communication). This may reflect a difference in the Tol-dependent translocation of pore-forming and enzymic E colicins. We therefore carried out (1) an in vivo assay to confirm that the mutant ColE9/Im9-His-tag complexes were still capable of binding to the BtuB receptor, and (2) an in vitro assay to confirm that the mutant ColE9/Im9His t tag complexes were still capable of DNase activity. The former is performed by a competition assay in which a mutant ColE9/Im9 complex is used to protect E. coli cells against cell killing by the native ColE9/ Im9-His - tag complex (Fig. 4). Each of the three purified mutant ColE9/Im9-His-tag complexes was able to protect $E$. coli cells. As a control in this experiment we used a His575Ala mutant ColE9/Im9-His - tag complex, which is biologically inactive due to a mutation in the DNase domain (Garinot-Schneider et al., 1996). The three TolA box mutants were capable of protecting $E$. coli cells at lower relative concentrations than the His575Ala mutant (Fig. 4). This may be due to blocking of the BtuB receptor as a result of the TolA box mutant proteins not being translocated. The three TolA box mutant proteins thus appear to have no defect in binding to the BtuB receptor and are therefore assumed to have no gross defect in their three-dimensional structure as a result of the alanine mutations. The latter assay is performed using a plasmid nicking assay (Wallis et al., 1992a, b, 1994) and shows that each of the three purified mutant colicin E9 proteins, when separated from Im9His - tag, were capable of DNase activity. In all cases the DNase activity was inhibited by the presence of $\operatorname{Im} 9$ protein in the assay (data not shown).

\section{DISCUSSION}

The results of this study show clearly that three of the five residues of the putative TolA box (Pilsl \& Braun, 1995a) are essential for the biological activity of colicin E9. The phenotype of the Ser37Ala mutant confirms the conclusion of earlier work with a Ser37Phe mutant of colicin E3 (Escuyer \& Mock, 1987). Alanine scanning mutagenesis of a total of 14 of the first 56 residues of colicin E9 revealed that only the three residues identified in the TolA box completely abolish the biological 
activity of colicin E9. Mutation of Ser34 and Ser40 to alanine results in colicin zones of inhibition which are slow to form and are hazy in comparison to the control, thus indicating some effect on biological activity. The zone of inhibition of the Ser40Ala mutant was also significantly smaller than that of the control culture. Although these results provide support for the hypothesis that the TolA box pentapeptide and the flanking Ser residues are important for biological activity, there is only indirect evidence that they are involved in Tol-dependent translocation. However, since we have demonstrated that the three mutant proteins are capable of binding to the $\mathrm{BtuB}$ receptor, and also exhibit DNase activity, it is certainly suggestive that mutations located in this domain of the protein are defective in translocation. We cannot at this stage exclude the possibility that the three TolA box mutants are biologically inactive because they become chemically and/or functionally labile within the bacterial cell. However, the large number of other mutations made in this region which do not affect biological activity, perhaps makes this an unlikely explanation. A more direct assay of the interaction of colicin E9 with proteins of the E. coli Tol-dependent translocation system will be required to answer this question unequivocally.

It is interesting that the suggested TolA box sequence of colicin K (GGTGA) contains an alanine residue at the fifth position (Pilsl \& Braun, 1995b). From our data with colicin E9, this would be expected to have a dramatic effect on the biological activity of the colicin. The only similar pentapeptide sequence in colicin N (SGAGS) also contains an alanine residue at the third position. Alanine scanning mutagenesis of the putative TolA boxes of colicin $\mathrm{K}$ and colicin $\mathrm{N}$ would be very informative. Progress in our understanding of the translocation of colicins will require knowledge of the three-dimensional structures of the translocation domain of Tol-dependent colicins, as has recently been obtained for the TonB-dependent colicin Ia (Wiener et al., 1997), together with the development of an in vitro or in vivo assay of translocation. The alanine mutants described in this work will be of value in dissecting the role of any interaction with proteins of the translocation machinery in the biological activity of colicin E9.

\section{ACKNOWLEDGEMENTS}

The authors would like to thank Dr Catriona Giffard for the gift of $\operatorname{Im} 9$, and Elaine Patrick for her excellent technical assistance. This research on colicins at UEA was supported by the Wellcome Trust. G.R.M. acknowledges the Wellcome Trust for its award of a Research Leave Fellowship.

\section{REFERENCES}

Bénédetti, H., Lazdunski, C. \& Lloubès, R. (1991). Protein import into Escherichia coli: colicins $\mathrm{A}$ and $\mathrm{E} 1$ interact with a component of their translocation system. EMBO J 10, 1989-1995.
Bénédetti, H., Letellier, L., Lloubès, R., Géli, V., Baty, D. \& Lazdunski, C. (1992). Study of the import mechanisms of colicins through protein engineering and $\mathrm{K}^{+}$efflux kinetics. In Bacteriocins, Microcins and Lantibiotics, (NATO ASI Series H65), pp. 215-223. Edited by R. James, C. Lazdunski \& F. Pattus. Berlin: Springer.

Benz, R., Maier, E. \& Gentschev, I. (1993). TolC of Escherichia coli functions as an outer-membrane channel. Zentralbl Bakteriol 278, 187-196.

Bouveret, E., Derouiche, R., Rigal, A., Lloubès, R., Lazdunski, C. \& Bénédetti, H. (1995). Peptidoglycan-associated lipoprotein-TolB interaction; a possible key to explaining the formation of contact sites between the inner and outer membranes of Escherichia coli. $J$ Biol Chem 270, 11071-11077.

Braun, V. (1995). Energy-coupled transport and signal transduction through the Gram-negative outer membrane via TonBExbB-ExbD-dependent receptor proteins. FEMS Microbiol Rev 16, 295-307.

Cooper, P. C. \& James, R. (1984). Two new E colicins, E8 and E9, produced by a strain of Escherichia coli. J Gen Microbiol 130, 209-215.

Cramer, W. A., Cohen, F. S., Merril, A. R. \& Song, H. Y. (1990). Structure and dynamics of the colicin E1 channel. Mol Microbiol 4, 519-526.

Di Masi, R. D., White, J. C., Schnaitman, C. A. \& Bradbeer, C. (1973). Transport of vitamin $B_{12}$ in Escherichia coli: common receptor sites for vitamin $B_{12}$ and the $E$ colicins on the outer membrane of the cell envelope. J Bacteriol 115, 506-513.

Escuyer, V. \& Mock, M. (1987). DNA sequence analysis of three missense mutations affecting colicin E3 bactericidal activity. Mol Microbiol 1, 82-85.

Garinot-Schneider, C. (1996). Mutational analysis of colicin E9. $\mathrm{PhD}$ thesis, University of East Anglia, Norwich.

Garinot-Schneider, C., Pommer, A. J., Moore, G. R., Kleanthous, C. \& James, R. (1996). Identification of putative active site residues in the DNase domain of colicin E9 by random mutagenesis. $J \mathrm{Mol}$ Biol 260, 731-742.

Gilson, L., Mahautey, H. \& Kolter, R. (1990). Genetic analysis of an MDR-like export system - the secretion of colicin V. EMBO $J$ 9, 3875-3884.

Isnard, M., Rigal, A., Lazzaroni, J.-C., Lazdunski, C. \& Lloubès, R. (1994). Maturation and localization of the TolB protein required for colicin import. J Bacteriol 176, 6392-6396.

Jakes, K. S., Zinder, N. D. \& Boon, T. (1974). Purification and properties of colicin E3 immunity protein. J Biol Chem 249, 438-444.

James, R., Kleanthous, C. \& Moore, G. R. (1996). The biology of E colicins: paradigms and paradoxes. Microbiology 142, 1569-1580.

Kampfenkel, K. \& Braun, V. (1993). Membrane topologies of the TolQ and TolR proteins of Escherichia coli; inactivation of TolQ by a missense mutation in the proposed first transmembrane helix. $J$ Bacteriol 175, 4485-4491.

Lau, P. C. K., Parsons, M. \& Uchimura, T. (1992). Molecular evolution of E colicin plasmids with emphasis on the endonuclease types. In Bacteriocins, Microcins and Lantibiotics, (NATO ASI Series H65), pp. 353-378. Edited by R. James, C. Lazdunski \& F. Pattus. Berlin: Springer.

Lazdunski, C. (1995). Colicin import and pore formation: a system for studying protein transport across membranes? Mol Microbiol 16, 1059-1066.

Levengood, S. K., Beyer, W. F., Jr \& Webster, R. E. (1991). TolA; 
a membrane protein involved in colicin uptake contains an extended helical region. Proc Natl Acad Sci USA 88, 5939-5943.

Masaki, H., Yajima, S., Akutsu-Koide, A., Ohta, T. \& Uozumi, T. (1992). Immunity specificity and evolution of the nuclease-type $E$ colicins. In Bacteriocins, Microcins and Lantibiotics (NATO ASI Series H65), pp. 379-395. Edited by R. James, C. Lazdunski \& F. Pattus. Berlin: Springer.

Mende, J. \& Braun, V. (1990). Import-defective colicin B derivatives mutated in the TonB box. Mol Microbiol 4, 1523-1533.

Pilsl, H. \& Braun, V. (1995a). Novel colicin 10: assignment of four domains to TonB- and TolC-dependent uptake via the Tsx receptor and to pore formation. Mol Microbiol 16, 57-67.

Pilsl, H. \& Braun, V. (1995b). Strong function-related homology betwen the pore-forming colicins $\mathrm{K}$ and 5. J Bacteriol 177, 6973-6977.

Sambrook, J., Fritsch, E. F. \& Maniatis, T. (1989). Molecular Cloning : a Laboratory Manual, 2nd edn. Cold Spring Harbor, NY: Cold Spring Harbor Laboratory.

Schramm, E., Mende, J., Braun, V. \& Kamp, R. M. (1987). Nucleotide sequence of colicin B activity gene $c b a$ : consensus pentapeptide among TonB-dependent colicins and receptors. J Bacteriol 169, 3350-3357.

Sidikaro, J. \& Nomura, M. (1974). E3 immunity substance. J Biol Chem 249, 445-453.
Wallis, R., Reilly, A., Rowe, A., Moore, G. R., James, R. \& Kleanthous, C. (1992a). In vivo and in vitro characterisation of overproduced colicin E9 immunity protein. Eur J Biochem 207, $687-695$.

Wallis, R., Moore, G. R., Kleanthous, C. \& James, R. (1992b). Molecular analysis of the protein-protein interaction between the E9 immunity protein and colicin E9. Eur J Biochem 210, 923-930.

Wallis, R., Reilly, A., Barnes, K., Abell, C., Campbell, D. G., Moore, G. R., James, R. \& Kleanthous, C. (1994). Tandem overproduction and characterisation of the nuclease domain of colicin E9 and its cognate inhibitor protein Im9. Eur J Biochem 220, 447-454.

Wandersman, C. \& Delepelaire, P. (1990). TolC, an Escherichia coli outer-membrane protein required for hemolysin secretion. Proc Natl Acad Sci USA 87, 4776-4780.

Watson, R., Rowsome, W., Tsao, J. \& Visentin, L. P. (1981). Identification and characterisation of $\mathrm{Col}$ plasmids from classical colicin E-producing strains. J Bacteriol 147, 569-577.

Webster, R. E. (1991). The tol gene products and the import of macromolecules into Escherichia coli. Mol Microbiol 5, 1005-1011.

Wiener, M., Freymann, D., Ghosh, P. \& Stroud, R. M. (1997). Crystal structure of colicin Ia. Nature 385, 461-464.

Received 11 March 1997; revised 6 May 1997; accepted 19 May 1997. 